\title{
O limiar entre a filosofia e a poesia em História natural da ditadura, de Teixeira Coelho
}

\section{The point where philosophy meets poetry in Natural History of Dictatorship by Teixera Coelho}

Ricardo Araújo Barberena

Pontifícia Universidade Católica do Rio Grande do Sul (PUCRS), Porto Alegre, Rio Grande do Sul, Brasil.

ricardobarberena@hotmail.com

Resumo: No limiar entre a filosofia e a poesia, existe uma territorialidade híbrida na qual se operam intercâmbios analógicos e ficções epistemológicas. E é justamente nessa área de contágio que se encontra a escritura de Teixeira Coelho em História natural da ditadura. Ou seria uma filosofia narrativizada? Afinal, como bem ressalta Sartre, em toda filosofia há uma "prosa literária escondida". No íntimo da filosofia, alojase a eterna tentação do poético, quer nos congratulemos com o fato, quer o deploremos. Esse inquietante texto contemporâneo de Teixeira Coelho transita por uma espacialidade em paralaxe no tocante aos diferentes sistemas de opressão e violência. Ao visitar o não-monumento a Walter Benjamin, a obra de León Ferrari ou os cárceres da ditadura brasileira, a obra propõe uma pungente reflexão fragmentada por estilhaços memorialísticos e por epifanias líricas. Como relâmpagos de poesia, a escritura filosóficopoética de Teixeira Coelho tece uma simultaneidade de sentidos: a ditadura como estado natural, a natureza da ditadura, a inacabada e constante crônica da depravação e cumplicidade com a repressão.

Palavras-chave: literatura contemporânea; ditadura; identidade; poesia do pensamento. 
Abstract: At the point where philosophy meets poetry, there is a hybrid territory in which operates analogical exchanges and epistemological fictions. And it is in precisely this area of contagion that Teixeira Coelho's writing resides in 'Natural History of Dictatorship'. Via a philosophical narrative. Or perhaps a narrated philosophy? After all, as Sartre points out, in all philosophy there is a "hidden literary prose". In the depths of philosophy, lies the eternal temptation of the poetic, whether we welcome or deplore it. This disturbing contemporary text by Teixeira Coelho moves by a spatiality in parallax as to the different systems of oppression and violence. Whether visiting the non-monument to Walter Benjamin, the work of Léon Ferrari, or the prisons of the Brazilian dictatorship, the work proposes a poignant reflection fragmented by shrapnel memoirs and lyrical epiphanies. Like poetic lightning, the philosophical-poetic writing by Teixeira Coelho weaves concurrent senses: the dictatorship as natural state, the nature of the dictatorship, the unfinished and constant chronicle of depravity and complicity with the repression.

Keywords: contemporary literature; dictatorship; identity; poetry of thought.

Recebido em 23 de março de 2015.

Aprovado em 17 de junho de 2015.

Há sempre na filosofia uma prosa literária escondida, uma ambiguidade dos termos. (J.P.Sartre)

Em filosofia, é só coberto de metáforas que pensamos. (Althusser)

\section{Poesia do pensamento: romance ou poema do intelecto?}

Antes de chegarmos ao livro de Teixeira Coelho, História natural da ditadura, publicado em 2006, é preciso que retrocedamos a dois pensadores "epistemologicamente consanguíneos" que se distanciam 
num intervalo exato de cem anos: Hans Vaihinger e George Steiner. O livro A filosofia do como se (1911), de Hans Vaihinger, autor denominado como o "espantalho da burguesia", foi cruelmente atacado depois da publicação ao ser avaliado enquanto um exercício teórico impróprio, se não amoral, nos meios universitários. Silenciado e achincalhado no mundo acadêmico, esse trabalho filosófico alcança um público mais amplo, construído por jornalistas e escritores (Bruno Bettelheim, por exemplo, destaca os efeitos libertadores desse livro). Ainda no rol de célebres admiradores da ousada pesquisa do filósofo alemão, cabe ressaltar a presença de pensadores seminais como Jorge Luis Borges, Aldous Huxley, Thomas Mann, Sigmund Freud e Einstein. Tendo em vista a pesquisa arrojada e ousada de Vaihinger, Arthur Fine passa a considerálo como uma espécie de quebra de paradigma científico análogo ao legado de Thomas Kuhn dos anos 1920. Mesmo diante de uma recepção pautada pela hostilidade, o filósofo consegue uma disseminação dos seus pressupostos epistemológicos nos quais a ficção eleva-se à mola principal da autocompreensão do pensamento. A partir de uma concepção ficcionista da teoria, Vaihinger ressalta como as ficções não representam obstáculos no caminho da razão, mas, ao contrário, são artifícios produtivos sem os quais as ciências não cumpririam boa parte das suas finalidades. Assim sendo, a ficção passa a ser compreendida enquanto protagonista no processo de articulação científica, pois a efabulação se assemelha a outas operações mentais, como indução e dedução. Nesse flanco de valorização da ficção, Vaihinger define o seu conceito: "como atividade fictícia no interior do pensamento lógico, há de se entender a produção e o emprego de métodos lógicos que procuram alcançar as finalidades do pensamento mediante conceitos auxiliares" (VAIHINGER, 2011, p. 44). Pensadas nesses termos, as ciências, sobretudo chamadas exatas, precisam operar com ficções - construções auxiliares da psique - para descrever o mundo real. E é aqui justamente que esse filósofo maldito ressalta a estrutura composta pela expressão como se enquanto um meio linguístico que permite associar ideias. Nesse sentido, em última instância, cabe lembrarmos das palavras de Mallarmé: pensar é libertar “o demônio da analogia" (MALLARMÉ, 1990, p. 65). Por intermédio de um minucioso arrazoado nos textos filosóficos canônicos, Vaihinger empreende uma verdadeira caça ao como se em múltiplos textos que compõem diferentes vertentes do pensamento ocidental. O como se força pela comparação, por analogias representadas, a identidade de elementos não idênticos; ou seja, uma vez que as ficções são formadas, elas substituem 
um dado real por um irreal, criando assim a ilusão da compreensão. Em sua ampla análise do emprego das ficções no campo científico, o filósofo evidencia como as ficções produzem ilhas de ordem na multiplicidade dos dados sensoriais. Deste modo, a matemática usa a ficção como produto de abstração assim como a física recorre a ficções na formulação do átomo: "A mais difundida das ficções que acabamos de designar semificção, é a classificação artificial" (VAIHINGER, 2011, p.131).

No livro Poesia do pensamento, de George Steiner, publicado em 2011, existe, em consonância com Vaihinger, uma defesa de uma poética da razão. Segundo esse pensador contemporâneo, não seria pertinente dissociar um sistema cognitivo ou epistemológico das suas convenções estilísticas, dos gêneros de expressão que prevalecem ou são contestados na sua própria época ou no seu próprio meio. Sob essa territorialidade na qual se avizinham poesia e epistemologia, torna-se imperioso um questionamento fulcral: até que ponto as metafísicas de Descartes e Espinosa são condicionadas pelos ideais sociais e instrumentais complexos do latim tardio? Em outras palavras, a prática científica estaria absolutamente norteada pela criação de uma nova linguagem, de um idioleto singular adequado ao propósito epistemológico. Derrida não poderia ter existido sem os jogos de palavras iniciados pelo surrealismo e pelo Dada, imunes às acrobacias da escrita automática. E é nesse pêndulo intercambiante entre poesia e epistemologia que Heidegger, a partir de sua máxima estruturante "O relâmpago tudo governa", pôs no centro do seu ensino um surrealismo cognitivo. Se ainda recorrermos ao legado de Wittgenstein, podemos referir o axioma "As rosas serão vermelhas no escuro?" - caracterizado justamente pela contaminação limiar entre a filosofia e a poesia. Não serão raros os exemplos na filosofia pautados por uma espécie de contrabando lírico no qual um determinado enigma lógico passa a ser metamorfoseado numa espécie de relâmpago de poesia. Em síntese, diríamos que tanto na filosofia como em literatura, o estilo é substância. Essa artesania ensaísta se presentifica numa amplitude retórica ou numa condensação lacônica que acaba por oferecer imagens e leituras do mundo contrastantes. Podemos afirmar, desse modo, que até mesmo a pontuação apresente-se epistemológica.

No íntimo da filosofia, aloja-se a eterna tentação do poético, quer nos congratulemos com o fato, quer o deploremos. Ao anarquizar os múltiplos estratos da sua gramática semântica, o pensador/escritor Samuel Beckett se transforma num miniaturista da imensidão. Através de poucas palavras e de vazios e silêncios, o dramaturgo irlandês possibilita-nos 
uma leitura vasta de sentimentos, identidades, angústias ao dizer pouco, ao dizer tudo. Imprescindível e pertinente observarmos que, nos ecos de Espinosa e de Schopenhauer, é frequente um dançar linguístico no qual o ritmo, a entoação e a flexão gramatical permitem ouvir ressoar os ossos desnudos da linguagem. Em muitos filósofos existem palavras muitas vezes monossílabas - que se comprimem contra o não-dito; entre a metafísica e a poesia, o ar carrega-se de ecos. Para George Steiner, é imperioso que se faça uma profunda aproximação entre um conjunto de textos filosóficos que se desenvolvem sob a pressão dos ideais literários, pois a lírica e a epistemologia se encontram num entre-lugar híbrido de plurais negociações e suplementações.

A agenda disciplinar contemporânea precisaria também dedicarse a examinar os contatos sinápticos entre raciocínio filosófico e expressão literária. Ao historicizar a filosofia, percebe-se que as fronteiras entre as narrativas de criação - ficções mitológico-alegóricas e textos filosóficos - mantiveram-se, durante muito tempo, inteiramente fluidas. A filosofia pré-socrática é de um magma metafórico que parece ser a erupção de um saber lírico-filosófico. Se ainda retrocedermos à obra de Heráclito, notaremos que a sua obscuridade faz incontestavelmente parte da sua sedução. Heráclito, quem sabe o mais fascinante dos pensadores-poetas, ilustra uma tradição e uma estética da matéria escura. Uma linhagem que reúne Píndaro, Góngora, Mallarmé, Paul Celan e Roland Barthes.

Na esteira sartreana, Steiner afirma que em toda a filosofia há uma prosa literária escondida, pois o pensamento filosófico não pode realizar-se senão "metaforicamente". Portanto, a linguagem da filosofia, como o leitor atento dos grandes filósofos deve reconhecer, é uma linguagem literária e não técnica. Pensada sob esse quadrante teórico, a filosofia assemelha-se à poesia. É um “poema do intelecto" (STEINER, 2011, p. 37) e representa “o ponto em que a prosa se aproxima mais da poesia" (STEINER, 2011, p. 25).

Ao repelir a usual narrativa folhetinesca, cujo maior intento é a fidelização do leitor através da avalanche de um encadeamento causal e linear, História natural da Ditatura, de Teixeira Coelho, instaura uma tessitura narrativa ensaística que não deixa de emitir juízos, confrontos e protestos contra os desvios éticos e estéticos da era da globalização. A linguagem se mostra urdida por uma artesania poético-filosófica na qual o narrador deixa de tatear conceitos ambíguos da pós-modernidade em detrimento de uma intensa reflexão no tocante às (de)rotas e devires do destino humano. Em determinada passagem do texto, o narrador, na sua condição de pensadorpoeta, constrói uma definição para a sua própria escritura: 
A terminologia é a poesia do pensamento - escreveu alguém em algum lugar em algum momento do passado, embora com outras palavras, mas de modo suficientemente claro para chamar a atenção de mais de um. Não sei quem foi e não tenho tempo agora para procurar uma atribuição correta da autoria. (COELHO, 2006, p. 199)

Evidencia-se aqui a intertextualidade crítico-teórica diante da obra de Hans Vaihinger e George Steiner. Sem um dicotômico alinhamento à esquerda ou à direita, o narrador rebate a soberba política oriunda da era da Guerra Fria de forma a estabelecer uma espécie de navegação anarquista lírico-filosófica a partir do questionamento das identidades que se consolidaram ao longo das (macro)narrativas hegemônicas, sustentadas pela bandeira da globalização oportunista. É importante salientar que se trata de um narrador (talvez um pensador-poeta, na esteira de Vainger e Steiner), mas não de um ensaísta que esteja unicamente preocupado com articulação de uma instrumentalização e de uma operacionalização teórica. Diante do tecido de memória e de reminiscência, costura-se uma série de fatos visceralmente marcados pela opressão da liberdade humana - desde a guilhotina e o terror da Revolução Francesa às ditaduras sangrentas da América Latina.

Ao poetizar/filosofar sobre o amontoando de cadáveres ao longo da história, o narrador acaba por desestabilizar o próprio sentimento de humano e de humanidade, pois o conhecimento puro, meramente logocêntrico, não produziu a libertação dos oprimidos, assim como não assegurou um projeto de felicidade coletiva. Nessa prospecção dolorosa, o conceito de estado de exceção se mostra fundamental na exposição da maior mentira que se camufla sob o manto da cidadania: a liberdade individual. Sob esse enfoque, o narrador descreve episódios documentados pelo artista Leon Ferrari no livro La bondosa crueldad, no qual se apresentam práticas exterminadoras da ditadura argentina, em 1976, contra suspeitos da área progressista da Igreja Católica. A presença da arte de Ferrari evidencia novamente um limiar entre a estética e a ética através da obra Nosotros no sabíamos, na qual contamos os mortos da ditadura por meio dos recortes de jornal.

Nesse caminho tanto filosófico quanto poético, o texto de Teixeira Coelho vai cartografando um espaço de pensamento/sentimento no qual existem diferentes contrabandos entre as artes e a filosofia. Neste espaço não surge, tampouco se ergue, qualquer fronteira nítida entre a filmografia de Eric Rohmer, os quadros de Turner, Whistler e Monet, os tempos de 
Salazar, Hitler, Mussolini, Stroessner, Stálin, Fidel, o fantasma de Aldo Moro ou a memória do Dops. Ao desestabilizar as barreiras entre o pensar e o sentir, o narrador pormenoriza as conjunturas derradeiras de uma "teoria da tristeza" (COELHO, 2006, p. 198), assim como Roland Barthes havia proposto a construção de uma "História das Lágrimas" (BARTHES, 2003, p. 60). Seja no Brasil, em 1964, seja na Alemanha nazista, desfilam uma série de acontecimentos ritmados pela marcha da força lírica do devir humano. Entre mortes e suicídios, paira um alento vital nutrido pelas paixões humanas que compõem um memorial de amar, de sentir, de pensar, de bestializar. Assim, é necessário que estejamos atentos à paralaxe entre poesia e filosofia:

Mas não um olhar com pretensão de ciência ou filosofia puras; antes, uma percepção contaminada pela própria presença, corpo e alma, dando-lhe a consistência das coisas vivas. E, finalmente, a vitalidade da linguagem romanesca, capaz de lidar com vozes outras sem se entregar inteiramente ao objeto. Eis aqui uma pálida tentativa de classificar esta fascinante História natural da ditadura, de Teixeira Coelho. Numa palavra, um ensaio escrito por um narrador (TEZZA, 2006, s/p).

No capítulo intitulado "Livro", o narrador, sob um tom entre o irônico e o farsesco, assumindo a "vergonha de narrar", discute limitações de uma escritura que sempre será um atestado de lembrança e de esquecimento. Baseado na construção de um forte libelo contra a institucionalização do poder totalitário na fase final do capitalismo, esse poema do intelecto se lança contra as injustiças no que diz respeito às aberturas "pseudodemocráticas", evidenciando-se, ao longo das páginas, que o ser humano é patologicamente inábil para viver num regime comunitário. Em diferentes momentos de reflexão, a liberdade é descrita como uma busca vã que, mesmo em ações incendiárias, acaba por ser vencida pelas autoridades governamentais e pelas leis. A fragilidade e a debilidade dessa liberdade humana estão expostas em múltiplos momentos de desilusão perante a uma lógica instrumentalizada que prioriza os mecanismos de acumulação através do lucro de ganhos especulativos. Fica então a pergunta que nos dilacera ao longo do livro: se o Estado de bem-estar se conquista pelo emprego das forças produtivas e se estas oferecem, de preferência, mercadorias de destruição em armas e ataques à natureza, como conduzir o paradoxo do "progresso" que nos rege desde o Iluminismo? Diante de tal paroxismo, a nação passa a ser 
entendida como uma comunidade atravessada pela impossibilidade de sistematizar os programas verdadeiramente democráticos no tocante à organicidade de uma paz social.

A corrupção do Senado Federal também é abordada na dramática História natural da ditadura, retratando-se, em tintas fortes, um poder executivo que legisla fartamente através de medidas provisórias. E seu aparelho repressor, segundo estatísticas fartamente divulgadas, julga alegados delitos e até comete execuções punitivas sem sequer ser molestado pela força dos fatos ou por sanções legais ou éticas. Já o poder judiciário, dada a sua imperfeição, tem se constituído em corporação homologatória da impunidade. O texto de Teixeira Coelho também se debruça sobre a suprema injustiça do modelo brasileiro que se observa na profunda desigualdade econômica e social. Ressalta-se que, segundo o IPEA (Instituto de Pesquisa Econômica Aplicada), a distância entre a menor renda pessoal e a maior é de 1714 vezes, enquanto nos países mais avançados economicamente a mesma comparação é de apenas 20 vezes. Daí se depreende outra indagação: seria suicida a humanidade? Mas a textura e contextura da narrativa de Teixeira Coelho não autoriza uma única conclusão. Como um lance de dados que flerta com o acaso, o texto líquido lírico-filosófico demonstra que a ficção ajuda a refletir sobre o real. E o pensamento a respeito do que nos circunda, a reflexão sobre o que nos afeta pode acabar por ajudar-nos a compreender, levarnos ao pensamento instigante e questionador, com viva alma atenta ao hoje e ao amanhã. Se nesse voltar reflexivo, não conseguimos alterar o passado, que, ao menos, saibamos sobreviver, afinal, se a literatura não nos ensina a caminhar, ela nos permite respirar.

\section{Livro Benjaminiano? Livro Constelação?}

No capítulo intitulado Portbou, o narrador relata diferentes epifanias ao visitar um monumento sob um vento feroz em "lugar nenhum". Paralelamente à trajetória do protagonista, passamos a acompanhar a jornada do filósofo Walter Benjamin ao transitar da França à Espanha, em 1933, até o dia em que o pensador amanheceu morto num quarto de hotel. A partir de uma espécie de turismo sinestésico de reificação e de estesia, o narrador inicia uma visita ao local em que Benjamin, uma espécie de Messias romântico, teria cometido suicídio em sua tentativa de fuga ao aparelho nazista. A narrativa é pormenorizada entre fragmentos de reminiscência e, ao construir um móbile de 
lembranças estilhaçadas, a narrativa, entre rastros de lirismo e filosofia, apresenta-se motivada por uma subjetividade anticartesiana. Através de uma escritura constelatória, menos preocupada em possuir o fenômeno do que em liberá-lo em seu próprio ser sensível, evidencia-se uma dança de elementos díspares em toda sua irredutível heterogeneidade: memórias, sentimentos, aforismas e emoções. A tessitura de narrativa-constelação recusa-se a ser igualada a uma essência metafísica, pois articula seus componentes de modo aberto. Daqui poderíamos importar a própria noção benjaminiana de constelação para definir os fluxos e devires do texto de Teixeira Coelho. A própria noção de constelação é também uma constelação, rica em alusões teóricas. Nesse sentido, para o teórico Terry Eagleton, a constelação:

leva em consideração as reconfigurações do cotidiano com seus efeitos de estranhamento do surrealismo, o sistema musical de Schoenberg e todo um estilo de sociologia microscópica na qual se estabelece uma nova relação entre parte e todo. (EAGLETON, 1993, p. 239)

Ainda segundo o teórico britânico, o conceito de constelação talvez seja uma das tentativas modernas mais originais para romper com versões tradicionais da totalidade. Pensado nesse sentido, o textoconstelação de Teixeira Coelho também representa uma resistência às formas mais paranoides do pensamento totalizante, valendo-se, em diferentes passagens, de uma celebração empirista do fragmento. A narrativa constelatória salvaguarda a particularidade, mas rompe com a identidade, explodindo o objeto num leque de elementos conflitivos o que leva, assim, à libertação de sua materialidade à custa da permanência de sua identidade. Ao recolher múltiplos elementos heterogêneos, o ato de constelar, ao longo da narrativa sobre a ditatura, implica num livre jogo de imaginação que lembra o oportunismo perverso do alegorista. Em termos mais amplos, poderíamos afirmar que a escritura-constelação seria uma mistura profana de positivismo e imprevisibilidade - combinação que Adorno detecta no surrealismo, cujas montagens lhe parecem envolver fetichismo associado a um subjetivismo arbitrário.

Como uma espécie de fantasia psicologista e filosófica, a narrativa de História natural da ditadura lança mão de subjetivismo que passa a abalar o continuum letal da história com as poucas armas que lhe são disponíveis: o choque, a alegoria, o estranhamento, as lascas heterogêneas de um tempo messiânico, a miniaturização, a nostalgia revolucionária, 
os traços de memória reativados. Frente aos pedaços desconexos da História, o livro de Teixeira Coelho aproxima-se ao pensamento de Walter Benjamin quanto ao resgate das ruínas de um progresso: os detritos da História, o excluído, o desviante, o abandonado. Tanto no pensamento do filósofo quanto no romance-ensaio contemporâneo, percebe-se a procura de uma história e de uma política surrealistas, que se liguem fortemente ao fragmento, à miniatura e à citação casual, na qual convergem esses fragmentos uns sobre os outros com um efeito politicamente explosivo, como o Messias que transfigura completamente o mundo através de mínimas intervenções sobre ele.

\section{0 pensamento fotografado}

A fotografia tem função central em A História natural da ditadura. Ao invés de pedagogicamente aguçarem e explicarem a narrativa líricofilosófica, as imagens reiteram o caráter opaco e deslizante de toda representação. Quando as fotografias são retiradas de sua solidão, de seus vínculos genealógicos, e inseridas em marcas temporais, passam a revelar outros nexos e temporalidades. As fotografias são utilizadas para tornar visível aquilo que, em nossa inércia, não conseguiríamos enxergar. Em conjunto, esses registros imagéticos, feitos em momentos e contextos tão distintos, narram um tipo de história involuntária, portadora de uma verdade ficcionalizada através de personagens frágeis, contingentes, arbitrários. Enquanto signos de uma flutuação do tempo, os elementos fotográficos testemunham subjetivamente os desdobramentos de um estado de exceção. Através de um movimento entre ficção, comentário e imaginação, as fotografias instituem uma dissipação de uma identidade refratária, uma quebra no espelho de Narciso, uma expressão de um corpo em metamorfose. Deste modo, o registro fotográfico proporciona o reingresso das imagens na vida cotidiana, sobretudo quando começa a tornar imagináveis os textos que permeavam um conhecimento letrado e difundido pelos diferentes espaços sociais. Como resultado imediato, nota-se a difusão da fotografia entre saber científico, vivência política e atividade artística, configurando-se em um novo espelho, às vezes cristalino, às vezes obscuro, que reflete o jogo do comportamento e conhecimento da sociedade moderna.

Num olhar de caça, o fotógrafo busca superfícies que se realizam simbolicamente enquanto cenas marcadas por encontro de conceitos permutados em imagens de hesitação e decisão no rastreamento de um 
momento mágico jamais visto: a morte de um guerrilheiro legendário, os primeiros passos num domínio lunar, a destruição de dois arranhacéus numa metrópole, um sorriso de uma criança anônima num parque qualquer, num minuto qualquer, num dia qualquer. Enquanto elementos onipresentes - fixados em jornais, vitrines, livros, paredes -, as fotografias significam conceitos programados que magicamente interagem no comportamento dos receptores. Imprescindível não observarmos que, ao se discutir a construção de tais imagens, um ponto parece bastante pertinente: teorizar sobre cenas registradas num filme fotográfico é também avaliar a articulação de um determinado ponto de vista que está associado à abertura de múltiplas visões de mundo. Com efeito, a intenção do fotógrafo - ou de qualquer outro indivíduo que utilize uma câmera - está centrada no desejo de codificar, em forma de imagens, os conceitos retidos num espaço-tempo da memória. A partir deste olhar particular, eterniza-se uma série de conceitos sob a superfície das imagens que passam a ser acessíveis a outras realidades sociais e culturais, a fim de se construir um arquivo de imagens compartilhado por toda uma coletividade. Se avaliarmos a fotografia como a produção de imagens técnicas que transcodificam conceitos em superfícies, torna-se bastante sustentável a investigação de um código fotográfico que não se realiza sem a presença de uma intenção humana atravessada por marcas ideológicas e culturais. Dito em outras palavras, poderíamos definir a utilização da fotografia em a História natural da ditadura como o acesso à imagem elaborada automaticamente no transcorrer de um jogo programado entre olhar humano e maquinaria, a fim de se produzir uma informação simbólica que, na sua superfície, acaba por preparar o receptor para um comportamento mágico. As imagens, ao longo da narrativa, essas planícies sobre as quais perscruta o olhar, podem ser captadas pelos registros fotográficos que gozam de status fisioquímico de credibilidade enquanto incontestáveis fragmentos constelatórios visuais de denúncia e evidência do mundo vivenciado por nossa existência.

Não há como negar que a fotografia, em diferentes momentos do romance, é reproduzida como um "testemunho de verdade" perante os acontecimentos sucedidos em determinada situação cotidiana e, devido a essa legitimidade conquistada, muitas imagens técnicas passaram a ser utilizadas para a veiculação de ideias sob os mais variados propósitos, das propagandas nazistas às campanhas da UNICEF. Nesse sentido, as fotografias demarcam o ponto de partida para que se inicie uma tentativa 
de compreensão de um dado minuto perdido num click instiganteprovocador ou apenas desinteressado: entretanto, tais imagens mostram um fragmento selecionado da aparência das coisas, das pessoas, dos fatos, tal como foram estética e ideologicamente congelados num dado momento de sua existência/ocorrência. Como as demais reflexões do narrador, a fotografia também se encontra atravessada por uma rede de ambiguidades resultantes de um jogo entre omissões calculadas e significados não-explícitos que, necessariamente, está aberto para um processo de decifração capaz de revelar um certo potencial informativo no interior de uma trama histórica e das suas diversas particularidades culturais, sociais, econômicas, políticas, religiosas.

Pensada nesses termos, a fotografia em História natural da ditadura está vinculada à captação do espaço/tempo que circunscreve os fragmentos de imagens registrados como forma de comprovação documental e como testemunho silencioso. Assim, a equação imagética da fotografia parece conter três elementos e dois condicionantes, todos de fundamental relevância. Em primeiro lugar, poderíamos pensar sobre a existência de um "assunto" que se realiza como o objeto de registro; em segundo, a maquinaria responsável pela extração das imagens tecnológicas e, por último, o autor que concebe a sua produção, a partir de uma ordem pessoal e/ou profissional, idealizada através de um complexo processo cultural/estético/técnico. Entretanto, esses três elementos são combinados em uma ação que está situada num certo lugar e numa certa época, ou seja, as imagens produzidas têm uma origem no tempo/espaço - são condicionadas por suas "coordenadas de situação". Daí se pode concluir que o tempo e o espaço, inscritos no registro fotográfico, caracterizam-se como fortes indicadores dos desdobramentos (culturais, políticos, sociais) que se materializam no microcosmo do foco de uma lente perdida num presente distante e num passado atual. Enquanto aventura estética/cultural/técnica, a fotografia no romance de Teixeira Coelho tem a faculdade de transformar os detalhes do mundo em documentos fiéis, isto é, de processar uma espécie de fotossíntese imagética do real, dos objetos concretos à revelação de um espelhado em papel. Conclui-se, então, que toda imagem fotográfica registra um dado fragmento específico do real - um "assunto" ou recorte espacial - que se encontra congelado num determinado momento de ocorrência, em outras palavras, uma "interrupção temporal".

Todavia, devemos nos perguntar se, afinal, pensar em fotografia é o mesmo que pensar em imagens técnicas? De certa forma, poderíamos 
discutir o ato de fotografar como um produto da técnica de um texto científico aplicado. Ontologicamente, a imagem fotográfica se constitui por intermediação de uma abstração e de uma reconstrução de novas figurações que antes haviam sido excluídas das dimensões de deciframento de um fenômeno concreto. Assim proposto, o significado da fotografia estaria aparentemente vinculado à impressão de formas automáticas sobre certas superfícies, como se fosse apenas uma cadeia complexa de processos óticos, químicos e mecânicos. No interior desse movimento de cumplicidade entre máquina e mão humana, percebe-se o surgimento de um tipo de observador que confia nas imagens técnicas tanto quanto confia em seus próprios olhos. No entanto, o registro fotográfico vai muito além das meras amarras tecnológicas. Afinal, esse caráter supostamente objetivo possibilita ao observador olhar para as fotografias não como imagens, mas, sim, como janelas. E, nos contornos dessas janelas, as imagens técnicas abrem espaço para uma realidade que é tão simbólica quanto são as demais representações pictóricas do mundo. Ao se revelar uma fotografia, dá-se início a uma cadeia de símbolos que devem ser decifrados para a compreensão dos seus significados. Mais ainda: estamos perante símbolos extremamente abstratos que codificam textos em imagens numa complexa rede de metacódigos, delineando-se um mundo pautado pela imaginação - a capacidade de transformar textos em imagens - e pela reconstrução de determinados conceitos relativos à automaticidade da impressão de uma realidade sobre a superfície da fotografia. Discutida nestes termos, a fotografia passa a ser entendida como um encadeamento de imagens - de janelas - que transcodificam processos em cenas, através de certa magia imagética compartilhada por um observador cansado dos efeitos e dos perigos da textolatria. Sob essa ótica, devemos nos lembrar da advertência de Susan Sontag: "colecionar fotos é colecionar o mundo" (SONTAG, 2004, p.13).

A partir da democratização do espelho fotográfico, abre-se um terreno fértil para uma pesquisa nos arquivos - nas evidências - que não integram os nossos bancos de imagens, a fim de contribuir para uma constante releitura dos signos imagéticos capacitados à subversão do corpus artístico e social. Nessa dimensão de significação, a fotografia se torna um instrumento crítico de aguçada mirada perante os vários discursos que tangenciam as realidades presentes no interior das fotos, conforme a existência de um envolvimento ideológico incompatível com uma suposta crença na neutralidade social de um olhar unívoco - sem resquícios de pluralidade identitária e cultural. No entanto, em 
História natural da ditatura, a fotografia tem um emprego fulcral visto que é através dessa ação de fotografar, representar e mimetizar o pensamento que se dá o desenvolvimento do romance. Quando o narrador está postulando uma belíssima reflexão sobre a fragmentação do devir humano, nos deparamos com uma fotografia-aforisma que corrobora para o entendimento de um ser/parecer constelar.

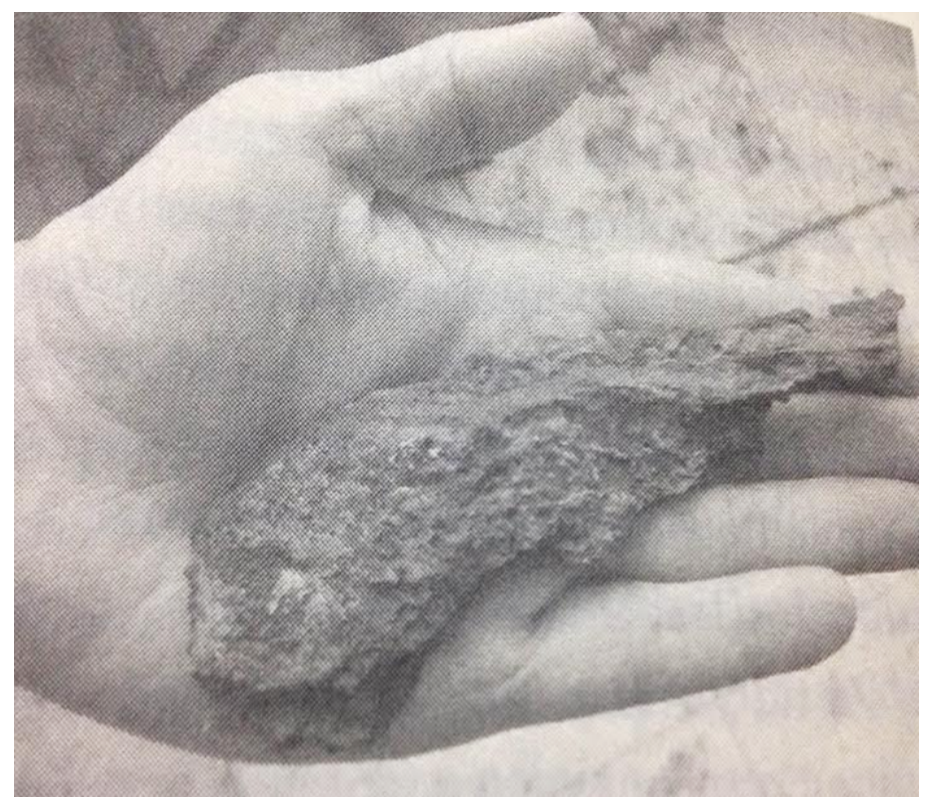

(Foto: COELHO, 2006, p. 30)

A fotografia é acompanhada por uma mediação lírico-filosófica que possibilita uma série de significações suplementares e intercambiáveis:

Lembrava-me um fragmento não de pedra mas de um fragmento de concreto que tirei do muro de Berlim, onde Walter Benjamin nasceu [...] e pendurei na parede de entrada de minha casa, in memoriam. Em memória do Muro, sim, mas sobretudo em memória de mim no Muro, sei disso. (COELHO, 2006, p. 29)

Podemos observar que as subjetividades e as confessionalidades não precisam ser ocultadas ou falseadas para que não seja exposto o 
discurso político-estético articulador dos significados construídos a cada click de evidências e de silêncios. Por consequência, o pensamento fotografado exposto, enquanto produto inacabado e polissêmico, possibilita a abertura irrestrita para múltiplas leituras - em termos de rejeição, emoção, indignação. A ativação destas outras interpretações revela o hiato entre uma versão do real pretensamente unitário e as lembranças daquele fugaz instante do ato do registro, do click que punge e mortifica, do arquivo que esconde e eterniza. Com sua energia fáustica e epifânica, a fotografia-pensamento parece emoldurar as frágeis materialidades de uma identidade vivenciada à beira do abismo da alteridade. Enquanto miniaturas de uma experiência despedaçada, as múltiplas fotografias ao longo do livro, como uma série de polaroids coléricas, oferecem um souvenir imagético de brutalidade que podemos levar para casa como prova do jamais visto e do jamais selecionado. As fotografias no texto de Teixeira Coelho também cartografam um doloroso memorial da dor e da subalternidade humana.

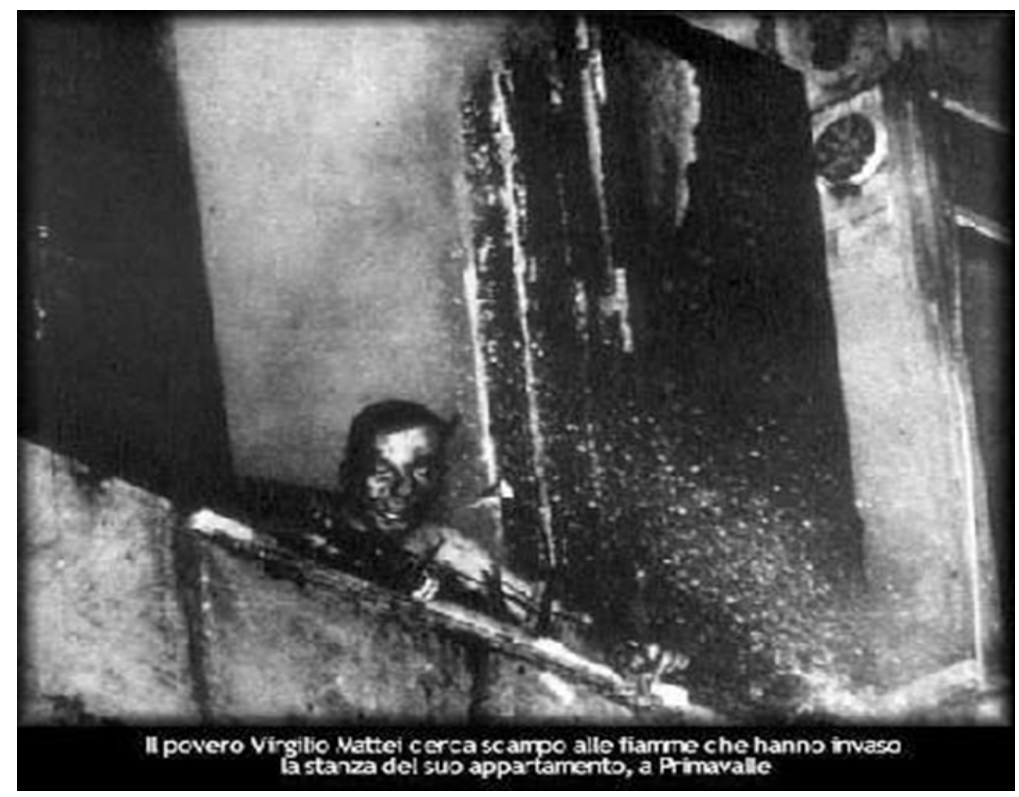

(Foto: COELHO, 2006, p. 169)

A fotografia anterior é seguida de uma dolorosa reflexão: "Três militantes do Potere Operaio jogaram combustível por baixo da porta 
do apartamento do líder direitista e atearam fogo" (COELHO, 2006, p.169). E num tom romanesco dramático conclui-se: "O líder visado não estava em casa, o fogo matou dois de seus filhos, um de 22 anos e outro de 8 , a mulher do dirigente e um filho menor se salvaram" (COELHO, 2006, p.169). A insólita imagem, recortada de um jornal, mostra os restos carbonizados do filho maior do qual, na verdade, só se via e reconhecia, na fotografia tirada do térreo, a cabeça junto ao beiral da janela do apartamento à qual ele assomara na tentativa frustrada de se salvar. No entanto, no transcorrer do romance, não encontraremos um safári de condolências que norteia uma historiografia conciliadora. Existe, sim, um horror voyeurístico que nos encoraja ao exercício de uma reflexão sobre aqueles lôbregos olhares na tentativa de questionar os acervos imagéticos da nossa história de violência, de ditatura, de opressão. Movidas pela pulsão de tornar inescurecível o que por pouca luz ilumina, as fotografias paralisam, ferem, acidentam e, no máximo da metáfora, mortificam nosso olhar a cada imagem reedificada.

Ao participar da vulnerabilidade crepuscular dos oprimidos, as imagens de História natural da ditadura suscitam um pathos fotográfico que encena uma catástrofe humana dantes exorcizada pelo ostracismo dos arquivos oficiais. Enquanto refúgios talismânicos do combate à amnésia social, essas fotos são capazes de abrir uma discussão acerca da representação - ou a não-representação - de certas minorias interditadas pelo matadouro imagético da unificação da história oficial.

\section{Pensar é pedreira}

Manoel de Barros, no poema "Retrato quase apagado em que se pode ver perfeitamente nada", adverte: "Pensar é uma pedreira. Estou sendo" (BARROS, 1998, p. 57). Talvez essa seja a melhor definição para História natural da ditadura, de Teixeira Coelho. Um pensar doloroso e poroso que se dobra sobre si mesmo num pedregoso movimento. Mas também um pensar composto por infinitas lascas de palavras-pedra. Como se fossem uma constelação de pedregulhos, os múltiplos estilhaços dançam ao acaso e também se atritam. Esses pedaços de pensamentos parecem estar sedimentados em híbridas camadas de poesia, metafísica, sociologia, historiografia. Para compreender esse fluxo de fragmentos, é fundamental que estejamos atentos à voz passiva perifrástica no tempo presente: "Estou sendo". Aqui o inacabado do gerúndio nos ensina muitas coisas. Dentre esses ensinamentos, está a fluidez de 
uma contemporaneidade na qual as áreas de escuridão não podem ser olvidadas, pois "contemporâneo é aquele que recebe em pleno rosto o facho de trevas que provém do seu tempo" (AGAMBEN, 2009, p. 60).

Entre espaços sombrios e nebulosos, o texto de Teixeira Coelho passeia noturnamente por um bosque lírico-filosófico no qual se torna possível neutralizar as luzes dos relatos institucionalizados e historicizados. Ao navegar por essa perversa obscuridade, o passageiro contemporâneo é aquele que percebe o escuro do seu tempo como algo que lhe concerne e não cessa de interpelá-lo. Ser contemporâneo é, antes de tudo, uma "questão de coragem" (AGAMBEN, 2009, p. 59) porque significa ser capaz não apenas de manter fixo o olhar no escuro da época, mas também de perceber nesse escuro uma luz que, dirigida para nós, distancia-se infinitamente de nós. Por isso os contemporâneos "são raros" (AGAMBEN, 2009, p. 59). Acima de tudo, trata-se de enfrentar o pensamento dilacerante e a consciência que liberta e aprisiona: "Eu sou o medo da lucidez" (BARROS, 1998, p. 57). E, mesmo que "chova na palavra" (BARROS, 1998, p. 57) quando esse contemporâneo escrever, ele seguirá no meio de sua pedreira e de seus pedregulhos-pensamento.

\section{Referências}

AGAMBEN, Giorgio. O que é o contemporâneo? E outros ensaios. Tradução: Vinícius Nicastro Honesko. Chapecó: Argos, 2010.

BARROS, Manoel de. O Guardador de Águas. Rio de Janeiro: Record, 1998.

BARTHES, Roland. Fragmentos de um discurso amoroso. Tradução: Márcia Valéria Martinez de Aguilar. São Paulo: Martins Fontes, 2003.

COELHO, Teixeira. História natural da ditadura. São Paulo: Iluminuras, 2006.

EAGLETON, Terry. A Ideologia da Estética. Tradução: Mauro Sá Rego Costa. Rio de Janeiro: Jorge Zahar Editor, 1993.

MALLARMÉ, Stéphane. Poemas. Tradução: José Lino Grünewald. Rio de Janeiro: Nova Fronteira, 1990.

SONTAG, Susan. Sobre Fotografia. Tradução: Rubens Figueiredo. São Paulo: Companhia das Letras, 2004. 
STEINER, George. A Poesia do Pensamento. Tradução: Miguel Serras Pereira. Lisboa: Relógio D'Água Editores, 2011.

TEZZA, Cristóvão. Aventuras pela memória. Jornal Folha de São Paulo, Mais!, 3 de dezembro de 2006.

VAIHINGER, Hans. Tradução: Johannes Kretschmer. A Filosofia do como se. Chapecó: Argos, 2011. 